\title{
The Material Application of the 18th Century French Collection on the Literatures of History of Taiwan Written by Missionaries - Campaign Against Taiwan and Indigenous Image*
}

\author{
Lee Chao-Ying \\ National Dong Hwa University, Hualien, R.O.C., Taiwan
}

\begin{abstract}
In many mass uprising events occurred in Taiwan ruled by Qing Dynasty, Lin Shuang-Wen Event (1786) was the largest and also most affected. National Taiwan Museum of Fine Arts has collected a set of Campaign Against Taiwan printmakings which were made in order to record Emperor Qianlong in his old age putting down Lin Shuang-Wen Event. There are a total of 12 pieces as the full set of the printmakings, including Rescue at Zhuluo, Battle at Dapulin, Battle at Taivoan, Battle at Fangliao, Capture of Chuang Ta-Tien, Fukanggan Attack on Xiamen, and Victory Banquet, and the range of which was throughout the weastern of today's Taiwan, as the region of Hsinchu, Miaoli, Taichung, Changhua, Nantou, Yunlin, Chiayi, Tainan, Kaohsiung, and Pingtung, and therefore, its serious situation shaked Qing. L'Institut de France collected a number of letters of 18th century, displaying the information on Taiwan's aborigines that Jean-Joseph Marie Amiot recorded the entire process of Lin Shuang-Wen making himself king in Taiwan. This part of materials were not found in Chinese materials, quite valauble. In this thesis, a French version was translated to compare with Chinese materials, explaining what the similarities and differences, with corresponding paintings to interprete Qianlong's policy against the border ethnic minorities, and sketched out the political implications of the exchange at that time.
\end{abstract}

Keywords: Lin Shuang-Wen Event, Campaign Against Taiwan, correspondences, Jean-Joseph Marie Amiot

\section{Preface}

l'Institut de France (MS1517) collected a number of unpublished letter manuscript letters describing Lin Shuang-Wen Event, between Henri-Leonard-Jean-Baptiste Bertin (1719-1792) and a French missionary in Beijing.

This paper mainly refers to Lin Shuang-Wen Event, recorded by Jean-Joseph Marie Amiot beside Emperor Qianlong in Beijing, and because which is not quoted in the letters, this part is regarded as a non-citation mark in the letter, so the text of this part is not translated from literatures, closer to the field of oral data or the author's observation, recording the perspective of missionary and Beijing in watching the Lin

* This paper has been published in the first annual meeting of Taiwan Art History Research Society and academic seminar, March 25-26, 2017, Taiwan.

Lee Chao-Ying, Associate Professor, Department of Ethnic Relations \& Cultures, National Dong Hwa University, Hualien, R.O.C., Taiwan. 
Shuang-Wen Event.

The letters were written by Jean-Joseph Marie, a French missionary in China, who translated many Chinese works, including classical theory, history, language, and Chinese art. He went to 1750 to Macao in 1750 , and to Beijing was summoned by the emperor in 1751; until the death, he did not leave Beijing. He is proficient in Chinese and Tatar languages, and translated Chinese classical scriptures, history, science, and literature to be published in France. The letters referred to the trading process of Qianlong's Ten Great Campaigns, and the major transaction was contributed through the French missionary in Beijing. The letters also referred that the Beijing missionary originally hoped to send the Campaign against Taiwan to France for engraving, but it was unsuccessful. Nevertheless, he still hoped to send the entire print to France, and in the letter described in detail the reason of Lin Shuang-Wen's rebellion, and how Qianlong looked at this event. In addition, it is not easy to cross the sea during the suppression process, the Qing soldiers never adapted to the maritime war. He also described the role of Taiwan peoples in these battles, and the Qing Dynasty officials in Taiwan were often corruptive due to the reason of system. They collected heavy tax, causing public grievances. After suppression of this event, the reward to the generals includes the descendants of the Taiwan indigenous leaders. The description of this part aroused the attention of Europe. It also combined with the geographical notes describing Taiwan at that time, hoping to understand the situation in the South China Sea. For this part, the author hopes to compare the Campaign against Taiwan with Qianlong's Ten Great Campaigns series, trying to explore the new theme: Taiwan's scenery, the image of indigenous peoples. As well as the real scene of general Agui personally experience the battle in Taiwan, which was also reviewed by Emperor Qianlong. Painted by Chinese painter and engraved by Chinese engravers in Beijing with the accuracy, it is based on the perspective of China print, to understand the meaning of this series of print and hope to show the other side of Taiwan as a social geographical environment.

\section{The Background and Context of Campaign Against Taiwan}

In French literatures, Jean-Joseph Marie Amiot mentioned Campaign Against Taiwan continuing the success of Qianlong's victory paintings, Jean-Joseph Marie Amiot as much as possible to recommend the emperor the prints can be engraved in France, France can get this power, just as before of the Qianlong's victory paintings, but in the end, he did not succeed. He mentioned that he would still send a print of Campaign against Taiwan to France. In the letter, especially in seven or eight pages, he described Lin Shuang-Wen Event, with the whole process, hoping to provide the latest information on Formosa for Europe.

From the official records of the Qing Dynasty, the 53rd year of Qianlong (1788) should be the year when Lin Shuang-Wen Event was suppressed. From the emperor, courtiers, to the provinces to participate in the suppression was the most important national event. In this year, Emperor Qianlong has been seventy Eight years old, based on the subjective and objective thinking, he hopes the victory battles to be identified as one of the most worthy of the record during his administration, to increase the footnote of the bright dynasty in military accomplishments. Emperor Qianlong who liked to compare everything with his grandfather Emperor Kangxi, in this matter, did not forget to compare with his grandfather, and mentioned in the imperially produced Fukanggan's Report of Capture of Zhuang Datian Records:

Moreover, in April of the $50^{\text {th }}$ year of Emperor Kangxi, Zhu Yi-Kui rose in rebellion in Taiwan, and then provincial military commander Shi Shibiao, and commander-in-chief Lan Tingchen marched on from Penghu in May, till they recovered the capital of Taiwan prefecture in June, spending a total of 7 days; until in the leap of June, Zhu Yi-Kui was 
captured, it spent a total of more than one month. Till April of the 1st year of Yongzheng, all rumps were completely exterminated. From Zhu Yi-Kui's rising in rebellion till suppression of whole Taiwan, the period was of about two years. On the other hand, Lin Shuang-Wen rose in rebellion in the November of 51st year, Huang Shijian and others bungled for one year; Fukanggan and others marched on from Lucaigang in November, during which they raised a siege of Zhuluo County, subdued Douliumen, and breached the rebel's den, and finally captured Lin Shuang-Wen in January of this year, for about a total of 42 days. And then they captured Zhuang Da-Tian for about a total of 32 days. From Lin Shuang-Wen's rising in rebellion to suppression of whole Taiwan, the period was about a total of one year and three months, which was more quickly than the victor of Lan Tingchen and others. ${ }^{1}$

Again, he made a comparison in The Praise and Preface of Suppressing Taiwan's Heroes Portrait,

Commanding troops cannot be easy! Former Emperor Guangwu, Han Dynasty had said: "Sending troops every time, my hair turned white". Not to mention I have been over 70 years old, about 80 years old, and my hair has long been half white; and the extension of the territory was more than Emperor Guangwu's far, even any hope for commanding troops! ${ }^{2}$

From these statements we can see Emperor Qianlong's joy and pride showed between the lines. Even in the 57th year of Qianlong, he wrote his life's ten great campaigns in the Ten Great Campaigns, "Ten campaigns: Two campaigns against the Dzungars, the pacification of Xinjiang, two suppression of the Jinchuan hill peoples, Pacification of Taiwan, Campaigns in Burma, and Campaign in Vietnam, and two receiving surrender of Gurkhas, a total of ten campaigns", among which pacification of Taiwan refers to the suppression of Lin Shuang-Wen Event.

The Lin Shuang-Wen Event started from November 27 of the 51st year of Qianlong when Tiandihui Party took Da Dun officially uprising, till Zhuang Da-Tian and others were captured on February 5 of the 53rd year of Qianlong, and the Qing army suppressed Taiwan North and South route, lasting one year and three months, which can be divided into three stages: from November of the 51st year to February of the 52nd year of Qianlong, a total of three months, belonging to the 1st stage. Tiandihui Party continuously took Changhua, Danshui, Zhuluo, Fongshan Prefectures/County, and the Qing army in a disadvantage, steadily lost. Fujian provincial commander-in-chief of navy, Huang Shi-Jian, provincial commander-in-chief of army, Ren Cheng'en successively crossed the sea to Taiwan; however, because he Qing army was weak and coward, following one another to wait and see; tired army and waste of money to bungle the military opportunities; from March to October of the 52nd year of Qianlong, a total of 7 months, belongs to the 2nd stage. The Qing court dismissed Huang Shijian, and Ren Cheng'en and repatriated to Beijing. MinZhe governor Chang Qing, counselors Heng Rui, and Lan Yuanmie successively crossed eastward the sea and repeatedly requested troops to aid, but the members of Tiandihui Party gathered more and more every day and gradually learned to offense and defense. Lin Shuang-Wen and Zhuang Da-Tian echoed north and south each other, showing every strong momentum. Chai Daji was trapped in Zhuluo, precariously; Chang Qingzhu guarded the capital of prefecture, unable to do anything. The Qing army blocked east and defended west, catching into the situation of fighting in south and north own way. From November of the 52nd year to February of the 53rd year of Qianlong, a total of 4 months belongs to the 3rd stage. For the side of Tiandihui Party, it showed interruption of army provisions

\footnotetext{
${ }^{1}$ Originally published in Emperor Qianlong's Veritable Records of Qing Dynasty, Vol. 1300, cited from Veritable Records of Qing Dynasty, Vol. 25, and p. 487. In addition, refer to Matters for Report of Comparing With the Time of Zhu Yi-Gui and Lin Shuang-Wen Two Cases, reported by He Shen, the Grand Secretary of the Wenhua Palace on March 11 of the 53rd year of Qianlong. Refers to Compilation of Taiwan's Archives in Ming and Qing Dynasties, the third series, Vol. 35, pp. 206-207.

2 Originally published in Emperor Qianlong's Veritable Records of Qing Dynasty, Vol. 1300, cited from Veritable Records of Qing Dynasty, Vol. 25, p. 488.
} 
and lack of appliances, and Quan and Yue villagers were irreconcilable. The Qing court ordered General Fukanggan, counselor Hailanqaled, who lead imperial bodyguardsand baturu, and the soldiers of Hunan, Guizhou, and Guangxi, as well as the surrendered barbarians who were trained and stationed in Sichuan to continuously cross eastward the sea; since the prestige of Qing army has been inspired, it rescued the besiege at Zhuluo, continuously conquered Douliumen, and Daliyi, and then defeated Jijipu, Xiaobantian, and Taivoan, and finally captured Lin Shuang-Wen and Zhuang Da-Tian, so that south and north areas were suppressed. ${ }^{3}$

The main reason for the finalization of whole Lin Shuang-Wen Event is indigenous peoples' assistance to officials and which is the reason for the failure of Lin Shuang-Wen.

In order to proclaim the exploits, the court following the example of the campaign pacifying East Turkestan, engraved this Campaign Against Taiwan etching. In the 53rd year of Qianlong (1788), the court painters Yao Wenhan, Yang Dazhang, Jia Quan, Xie Sui, and Zhuang Yude received the imperial command to paint, and then sent to Ruyi Hall of imperial workshop for engraving and printing, which was successively completed in the 56th year and the 57th year of Qianlong (1791-1792). The full painting includes 12 pieces, on each of which there was Emperor Qianlong's inscription of fighting narration. It can be seen he was careful about the painting. In fact, Emperor Qianlong has begun to write the combining sentences for recording events as early as before the war was pacified. On February 1, of the 53rd year of Qianlong, Emperor Qianlong's Veritable Records of Qing Dynasty recorded: “The emperor feasted grand secretaries and members of Hanlin academy in Zhonghu Gong to make the combining sentences for pacification of Taiwan." ${ }^{4}$ After receiving the imperial edict, Fukanggan drew the draft of terrain and path everywhere, but because the skill of painting and framing in Taiwan was not entirely satisfactory, he caused another painting and framing after back to inland, and personally brought to Reho for the emperor's review. After review, Emperor Qianlong said, the eight places as Chiayi County, Douliumen, Shuishalian, Daliyi, Jijipu, Xiaobantian, Laoquqi, and Langqiao in the paintings drawn by Fukanggan were same as the patterns provided by the Grand Council (Junjichu). In addition to above eight places, Fukanggan drew another eight places as Xinghuadian, Dapaizhu, Dapulin, Yiowunai Tribe, Taivoan, Niuchouzhuang, Fanglia, and Shuili Tribe where captured Lin Shuang-Wen's families, which were also presented to the Grand Council (Junjichu) for the emperor's selection. After the emperor decided, the Grand Council (Junjichu) pasted the name high-ranking officials leading the troops, and of battle leader on the painting, and summarized the sentence reported to the emperor. The employer's poems after being released were delivered to Rudi Hall for inscribing on the campaign painting. In addition, in terms of performance, although the bronze engraving technique was from Europe, comparing to the first set of East Turkestan Campaign $^{5}$ full of Western style realistic skills, which the Qing court ordered western missionaries come to China such as Giuseppe Castiglione and others to draw in the 25th year of Qianlong (1760), and sent to France for production, this set of Campaign Against Taiwan has returned to the taste of a few Chinese paintings, the two western realism elements as the perspective of figure and scene and the creation of light and shadow became dull, but used the traditional Chinese panorama composition method, presenting by segment the rich story in a picture from near to far, plus the rock profile composed by Chinese landscape painting, and the

\footnotetext{
${ }^{3}$ National Palace Museum Series Editorial Board, An Study on Emperor Qianlong's Ten Great Campaigns. Taipei: National Palace Museum, 1982, p. 247.

${ }^{4}$ Originally published in Emperor Qianlong's Veritable Records of Qing Dynasty, Vol. 1298, cited from Veritable Records of Qing Dynasty, Vol. 25, p. 441.

5 Lu Hsueh-Yen, Lou Tong Zhu Sheng-The Qing Dynasty Victory Campaign Print Collected by National Palace Museum, pp. 40-51.
} 
shadow was made like the wrinkling and rubbing ink effect, with mostly staff age vegetation for the traditional method of outlining leaves, so that the paintings showed a different style from the West. ${ }^{6}$ It can be seen from the previous cited content that this set of painting is in accordance with the report of Fukanggan who was the commander to Taiwan to supervise the campaign, verified by the Grand Council (Junjichu), and then the Emperor Qianlong personally reviewed and checked before printing, so the picture showed accurate and rigorous situation.

\section{Lin Shuang-Wen Event in the French Letters Corresponding to the New Features of Campaign Against Taiwan}

1. Several new focuses on Lin Shuang-Wen Event in French letters:

(1) From the perspective of Emperor Qianlong watch the empire.

The literatures written by French Jean-Joseph Marie Amiot are set forth as follows, who watched the empire from the perspective of Emperor Qianlong.

After being pacified, Taiwan, the island was finally tamed in the Qing Empire; now both inside and outside of the island are very calm, and the emperor wished to commemorate the campaign. Since having been ascended the throne, he thanked all the officials who had assisted him in the reign of the emperor. He was especially grateful to his ancestors for keeping his old age healthy, still with enthusiasm and did not appoint others, such as his sons administrators; he could not be replaced. ${ }^{7}$

The text shows his special respect for the rites, while charged with multiple roles, attributed to the kings who held the reins in the history, but also specifically mentioned Manchu ethnic groups, and pointed out the special identity of Manchu and other ethnic groups.

This year is the 53rd year for the rule, so he began to commemorate the ceremony. These rituals are mainly for the emperor, he is also a priest, the country's leader, and the emperor's father, each title gives him some responsibilities and obligations. He finished this task with the most devout and cautious mood. He especially thanks to the grace of Chinese God and prays for Chinese God and his ancestors, in other words the emperors from Fuxi to Yongcheng gave him new strength. He prayed before the emperor tablets in the imperial temple. ${ }^{8}$

Gradually, his birthday has also become a political show, showing his national strength and political prestige and ethnic policy.

He obeyed the law of the emperor ruled from ancient times, especially in the way of Manchuria to express respect to his ancestors, from the princes of the ages, and his descendants of the future. He also expressed respect to the nobility, officials, and representatives of the Han nationality from the provinces. In banquet and fireworks occasions, he treated Mongolian prince with the court's etiquette.

(2) The Qing Dynasty in Taiwan's corrupt officials caused public grievances, and Lin Shuang-Wen was portrayed as a hero; the description on Lin Shuang-Wen is different from the Chinese literatures, where Lin Shuang-Wen was depicted as a hero.

\footnotetext{
${ }^{6}$ Ho Meng-Hou, Taiwan Indigenous People in Lin Shuang-Wen Event in Qing Dynasty, National Palace Museum Academic Quarterly, Vol. 26, No. 4 (Taipei: National Palace Museum, 1999 summer), p. 127.

7 1'Institut de France, MS1517, the letter written by Jean-Joseph Marie Amiot to Bertin, No. July 1, 1788, p. 34.

8 l'Institut de France, MS1517, the letter written by Jean-Joseph Marie Amiot to Bertin, No. July 1, 1788, back of p. 34.

9 l'Institut de France, MS1517, the letter written by Jean-Joseph Marie Amiot to Bertin, No. July 1, 1788, back of p. 34 and front of p. 35 .
} 
The popular grievance will happen sooner or later. Two years ago it happened. The significant spark came from a morally citizen who was oppressed and extorted by officials. The citizen claimed to be Lin Shuang-Wen, who came from generations of government officials and literati, He was called "Xiu Cai", probably the qualification admitted to current university after the exam. He was pleased that the title had him a distinguished rank among all the citizens. He gave up the literati career, and dedicated to business to earn more money. He was the leader of all the sugar mills, and he with his own funds to create wealth. Sugar was the most important product of the island, not only could be self-sufficient, but also can be supplied to China. ${ }^{10}$

Lin Shuang-Wen was described as Xiu Cai and the oppressed citizen, but in China's historical data only mentioned that he had worked in the bureaucracy, he was not Xiu Cai family. This view from the oral still cannot be explained. The reason why these thieves became thieves was because of poverty. Lin Shuang-Wen wanted to be able to counsel them to find a job. His relief of the thief's deeds disclosed causing the jealousy of the officers and soldiers to extort Lin Shuang-Wen. This part is in line with the Chinese literatures referring to the greed and extortion of Taiwan's officials.

In addition, there was a feature of Campaign Against Taiwan quite different from the previous two victory paintings. In the pacification of East Turkestan and two Jinchuans, the "Presented with Prisoners" showed presenting the head of rebel leader after surrender. In this regard, we can see that the significance of the border chaos leader and of the civil commotion leader is quite different to Emperor Qianlong. On the occasion of the spread of Lin Shuang-Wen Event, Emperor Qianlong has always been every concerned about capture of Lin Shuang-Wen, Zhuang Da-Tian: "If Lin Shuang-Wen was killed or suicided, or escaped, no punishment can be shown." 11

So in the Campaign Against Taiwan, it recorded the scene depicting capture of rebel leader never had in the previous etching victory paintings. From literatures, we cannot know how Lin Shuang-Wen's saying and action was when he was arrested; but this Capture of the Rebel Leader Lin Shuang-Wen (Figure 1) is quite interesting. Lin Shuang-Wen in the picture (Figure 1-1) was surrounded by soldiers. His left hand was tied and right hand was pulled; his face turned left, showing cultured looks, and stood upright that was very different from "kneel to beg death" wanted by emperor Qianlong. However, from the production of the point of view, the moment to catch should more focus on the "capture" which the emperor extremely cared about. ${ }^{12}$

\footnotetext{
${ }_{10}$ 1'Institut de France, MS1517, the letter written by Jean-Joseph Marie Amiot to Bertin, No. July 1, 1788, p. 39.

${ }^{11}$ Hsin-Wei Li (2012). The Creation of Copper-Engraved Battle Prints in the Era of Emperor Qianlong: From East Turkestan Campaign to Taiwan Campaign (Unpublished master thesis). Graduate Institute of Art History, National Taiwan University, Taipei, p. 68.

${ }^{12}$ Hsin-Wei Li (2012). Op. cit., pp.68-69.
} 


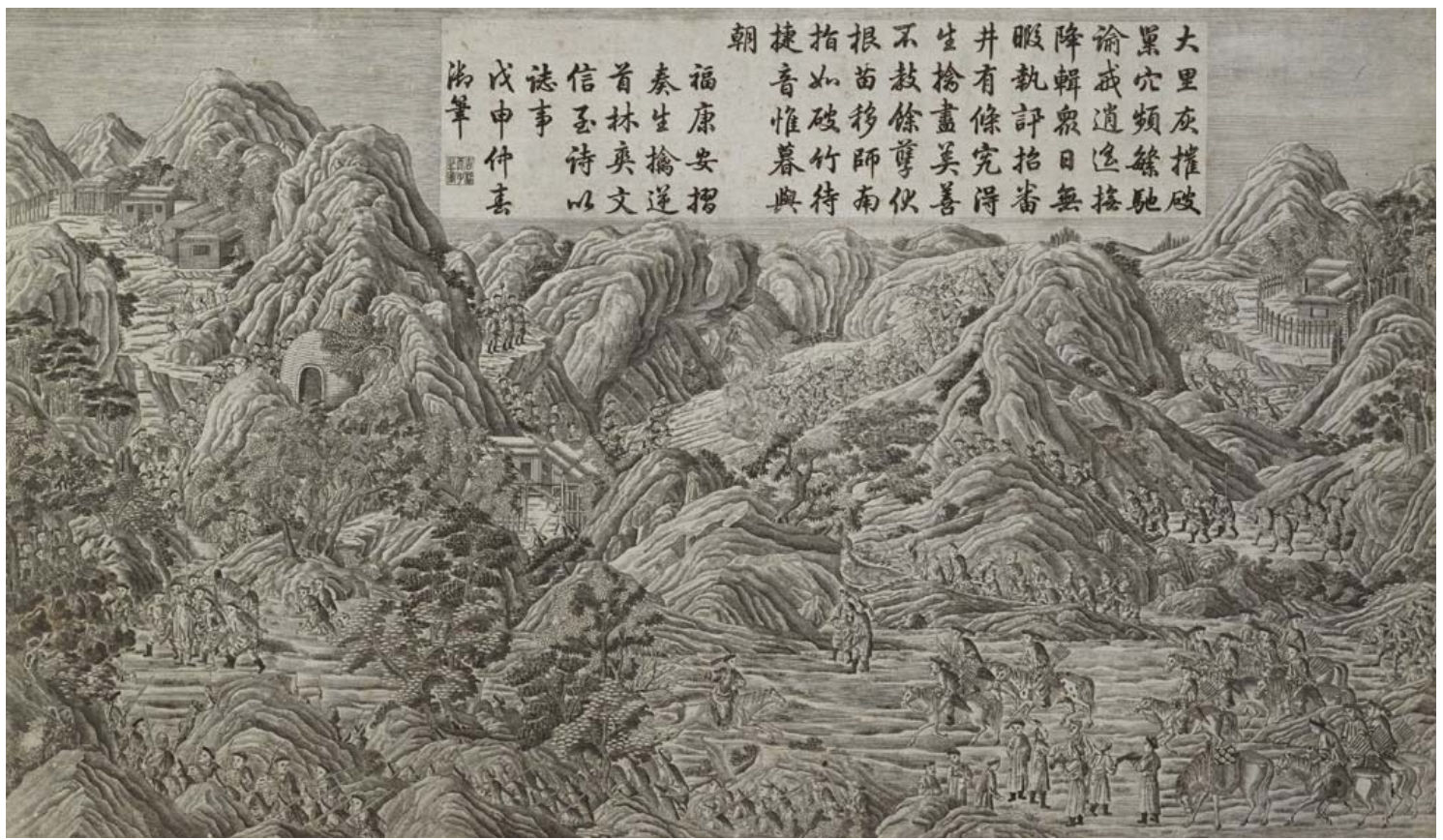

Figure 1. Capture of the rebel leader Lin Shuang-Wen.

Source of image: National Taiwan Museum of Fine Arts.

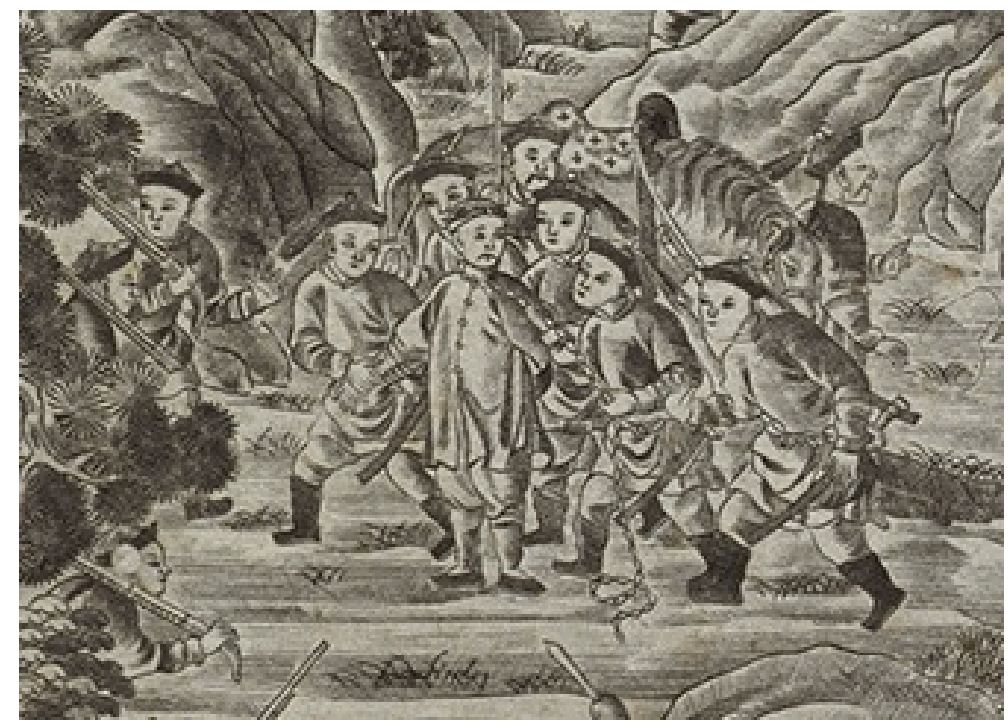

Figure 1-1. Capture of Lin Shuang-Wenin the lower left corner of the Campaign Against Taiwan, Capture of Lin Shuang-Wen in Laoquqi.

Source of image: National Taiwan Museum of Fine Arts

I have heard that there are intimate relationships with these robbers. Now they often rob the travelers and they spread everywhere in the city. Every night they will get the bell in the house, what do you think? Do you agree with them or do you want to provide these bad tools causing some revolution? People like you cannot be trusted. Until now you have a good reputation among the islanders you have a glorious class, among the officials of the ancestors or literati, your family is from traditional literati, although now you are engaged in the business industry. Please answer me not to have any concealment, and honestly recognize the truth. Now the people to whom you provided the answer are not an official, but as your friend, I want to lead you out of bad behavior. Lin Shuang-Wen answered: I do not have any conversation or trade, or any deal with these thieves, as you have just said. That's true, I have given sixty unfortunate people some money, in order 
to help them out of poverty, and save them almost in the state of starvation, so that they can survive, I think good behavior for you is a crime.

All the robbers supported Lin Shuang-Wen and supported him to do the king, and gave his emperor's name, Zhang Tianjing. In one of my letters, I had told you the impact of the event on Beijing. This was a monk's event, or is like a sage who has the ability to do miracles. This rebel is like a saint, who has collected thirty silver, and jewels or anything else for his magical intent, to the judge, just as to do a job not according to the appropriate law. He used the trust of some stupid foolish people and in some superstitious practice. All of them were sentenced to death. ${ }^{13}$

In French literatures, Lin Shuang-Wen and others was described as a group of chivalrous people who uprose by dissatisfaction with official fraud. Chinese historical materials emphasized mainly he was supported by the party of Tiandihui and officials' blackmail.

(3) The most difficult part in campaign against Lin Shuang-Wen was the unfamiliarity with Taiwan and Taiwan's strait. This part can be seen in Campaign Against Taiwan with more than two or three paintings of sea wars, different from the previous Qianlong's victory paintings.

Hsin-Wei Li (2012), The Creation of Copper-Engraved Battle Prints in the Era of Emperor Qianlong: From East Turkestan Campaign to Taiwan Campaign pointed out:

If classify the ten battles selected in the Campaign Against Taiwan according to the terrain, its diversity is much higher than the previous two sets of victory painting. For the main battlefield in plains, mostly showed attacking county seat, for example: Rescue at Zhuluo, Battle of Dabulin (Figure 2), Conquer of Douliumen, Battle at Daliyi (Figure 3), Battle at Jijipu (Figure 4); for the main battlefield in mountains, the paintings showed the followed action of pursuit and searching mountain: Attack on the mountain Xiaobantian, Capture of the Rebel Leader Lin Shuang-Wen, Battle at Taivoan (Figure 5); as for attack by land and sea to prevent from remained soldiers absconding can be seen in Battle at Fangliao and Capture of Zhuang Da-Tian. In those three different terrains, we can see the Qing army's attack mode different from past. The most obvious was the vigorous shelling in the flat as Battle at Daliyi (Figures 3). From the existing painting Shore Guard by Barbarians drawn by Inō Kanori (Figure 6), it can be seen Daliyi was flat, next to the river. Fukanggan et al.'s written reports mainly described how the Qing army approached the river: When attacked Daliyi, due to too deep steam, officers rode first, and then the stationed soldiers in Guangdong and Guangxi also arrived, crossing the river to fight the enemy. When the sky faded, they divided units waiting for dawn. However, the enemy's constantly night attacks were counterattacked by the Qing army five or six times, "Crushed the rebels overnight, every shot told". On the description of the siege was simpler, only accounted for the rebels rushing into Dailiyi from southwest and northwest gates respectively the next day. However, the Qing army with long distance strong firepower, concentrated to shell the middle of Daliyi, across a small ditch, often should have a fire line straight to fight bamboo grille; in the middle of the picture, curl fire enveloped the whole city. From the foreground lower right and bottom left, we can see the artillery operated the turret, and the rear soldiers moved out the ammunition from the barrel for filling; in the lower part of the picture, the situation that the soldiers' lugged ammunition for supply also can be seen. This large-scale scene with guns bombardment was never seen before in the parts two victory paintings. In the entire Campaign Against Taiwan, can be clearly seen the attack mode stressed that infantry with guns attack and cavalry defense. In addition to Battle at Daliyi, there are Conquer of Douliumen and Battle of Jijipu.

${ }^{13}$ l'Institut de France, MS1517, the letter written by Jean-Joseph Marie Amiot to Bertin, No. July 1, 1788, pp. 39-40. 


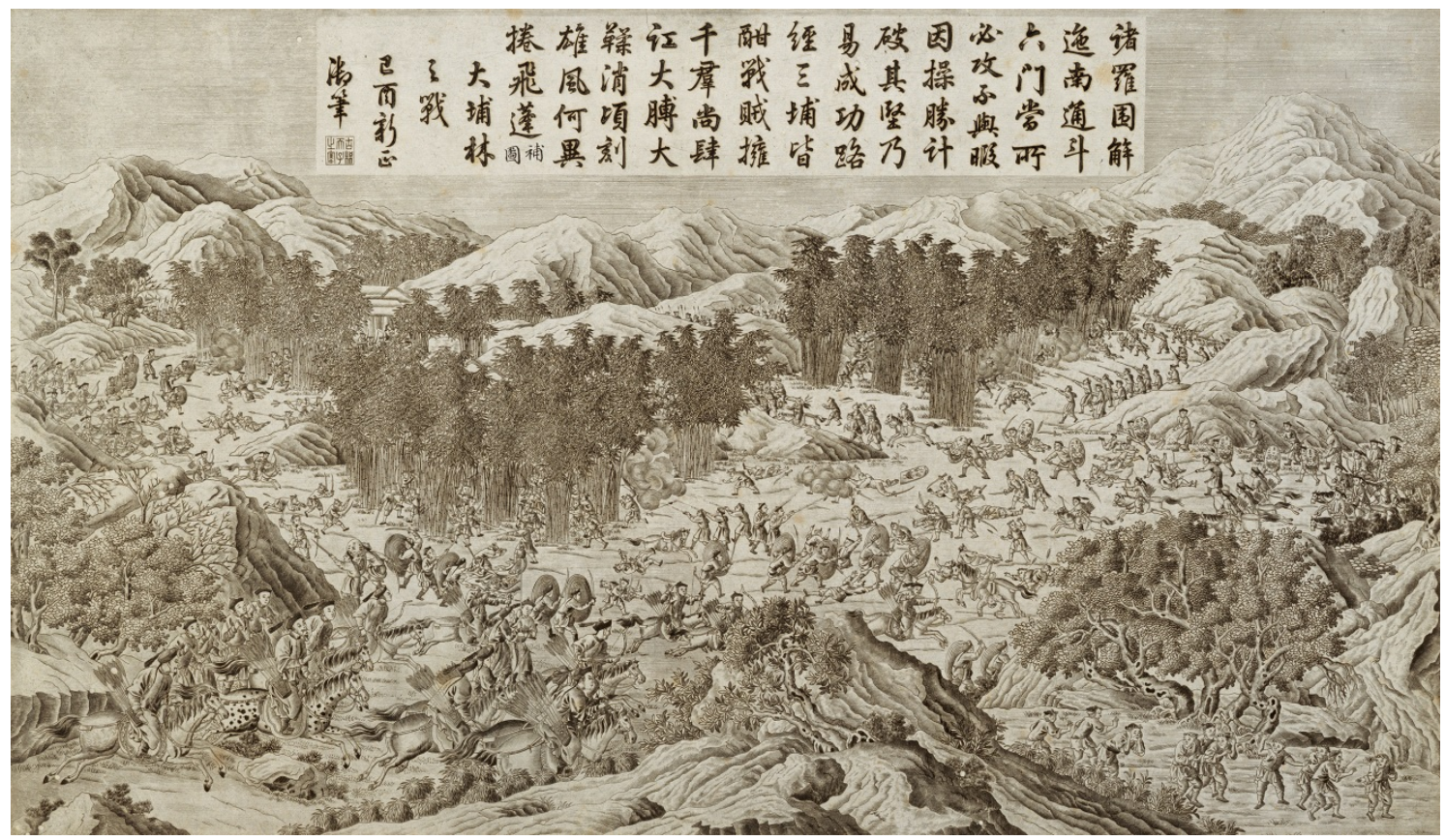

Figure 2. Campaign against Taiwan-Battle of Dabulin.

Emperor Qianlong, Qing Dynasty/ink printing on coated paper.

$58 \times 92.5 \mathrm{~cm}$.

Dapulin, located in today's Dapulin Township, Chiayi County. On October of the 52nd year of Qianlong (1787), Fukanggan led the troops crossing the straits to Taiwan. In November, he recovered the Zhuluo Countyseat which was besieged by Lin Shuang-Wen army, and in-depth pursuit of other Lin Shuang-Wen's associates. The two sides battled in Dapulin. In the picture, the Qing army waved knife and held shield, or shot, or rode for slaughtering. The fierce fighting can be seen at that time.

Source of image: National Taiwan Museum ofFine Arts.

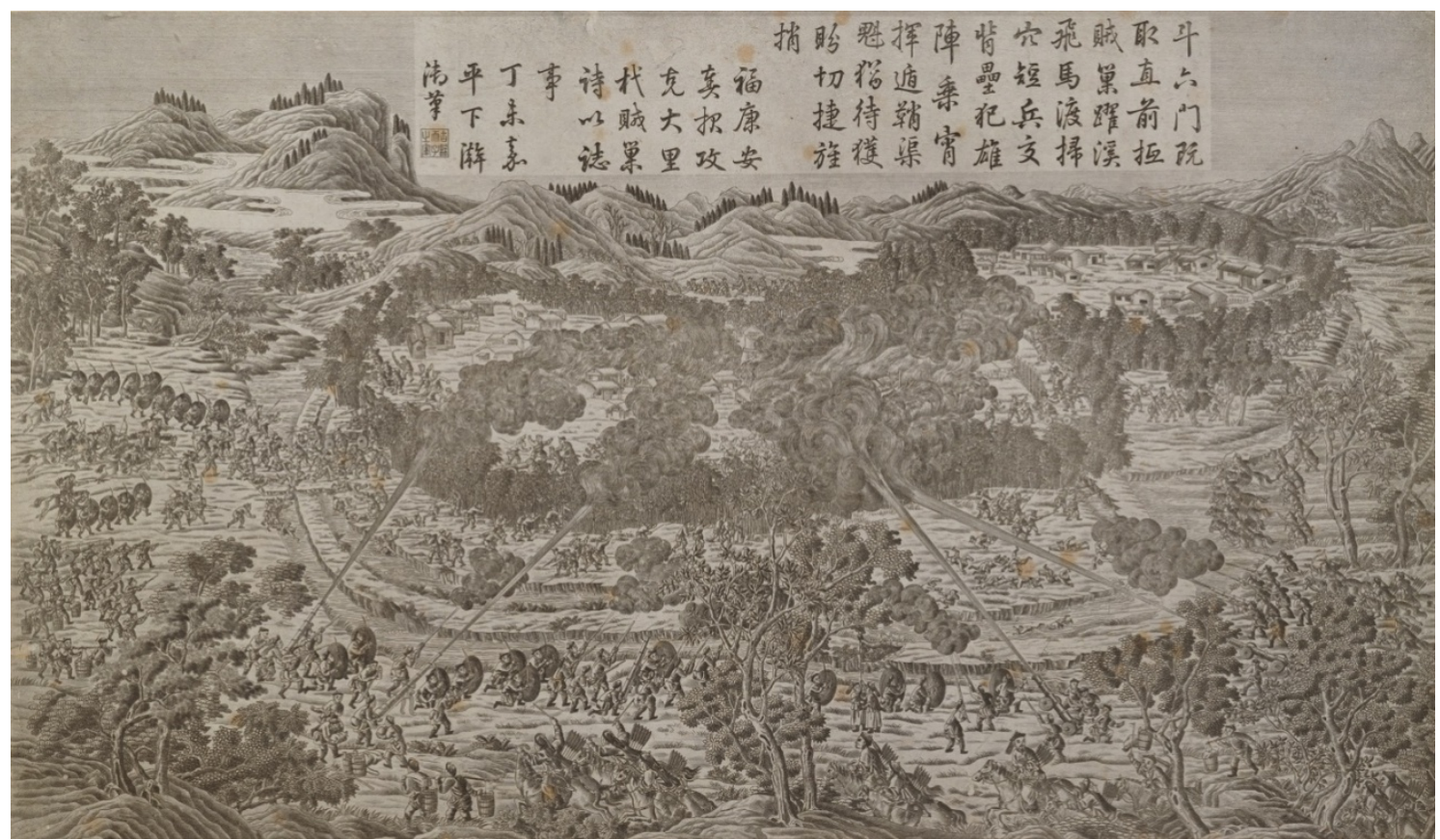

Figure 3.Campaign against Taiwan — Conquer of Daliyi.

Source of image: National Taiwan Museum ofFine Arts. 


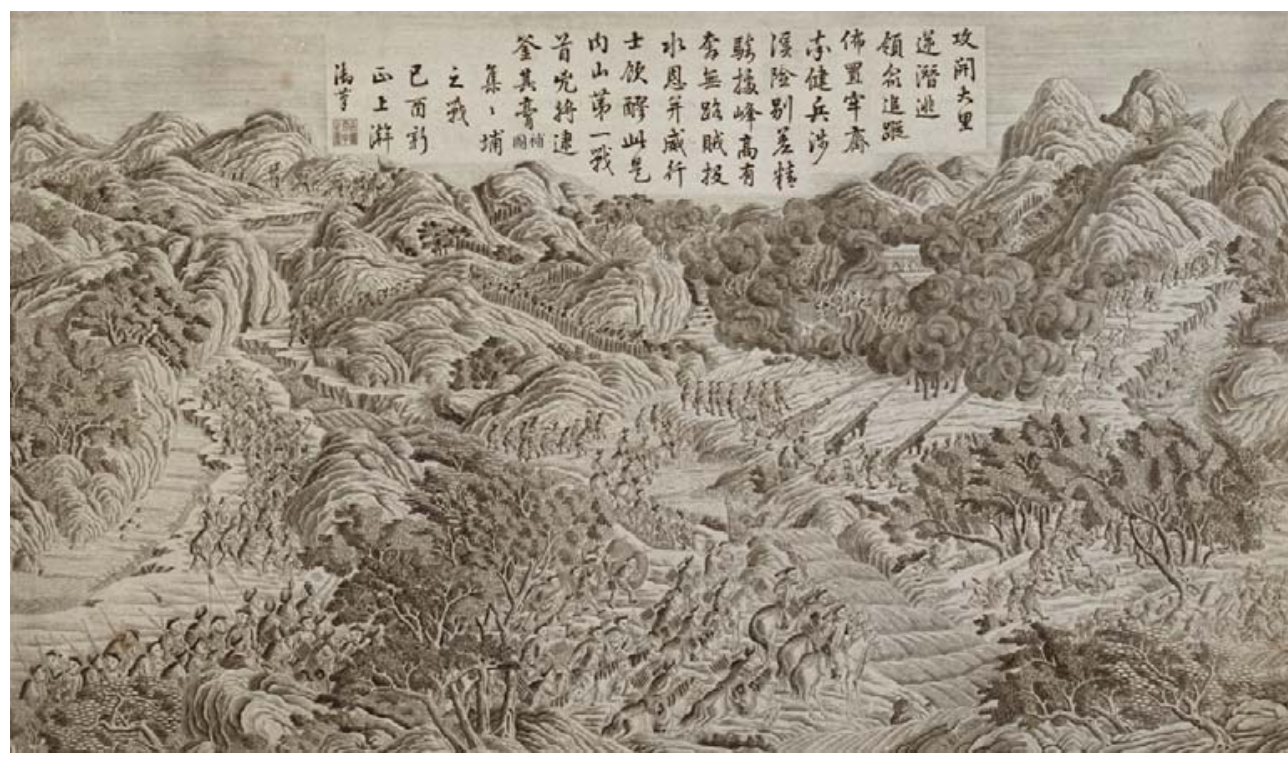

Figure 4. Campaign against Taiwan-Battle at Jijipu.

Emperor Qianlong, Qing Dynasty/ink printing on coated paper.

$58 \times 92.5 \mathrm{~cm}$.

On December of the 52nd year of Qianlong, Fukanggan led his troops toward north from Zhulo County, massively sieged other Lin Shuang-Wen's associates who stationed in Jijipu (now Jiji Town, Nantou County). In the picture, the guns shot together by both parties' army. The Qing army used mountain terrain for roundabout, or crossing Zhuoshui River faced the enemy. In this campaign, Fukanggan and Hailanqa forces successfully defeated the rebels, and captured Lin Shuang-Wen's family. Source of image: National Taiwan Museum of Fine Arts.

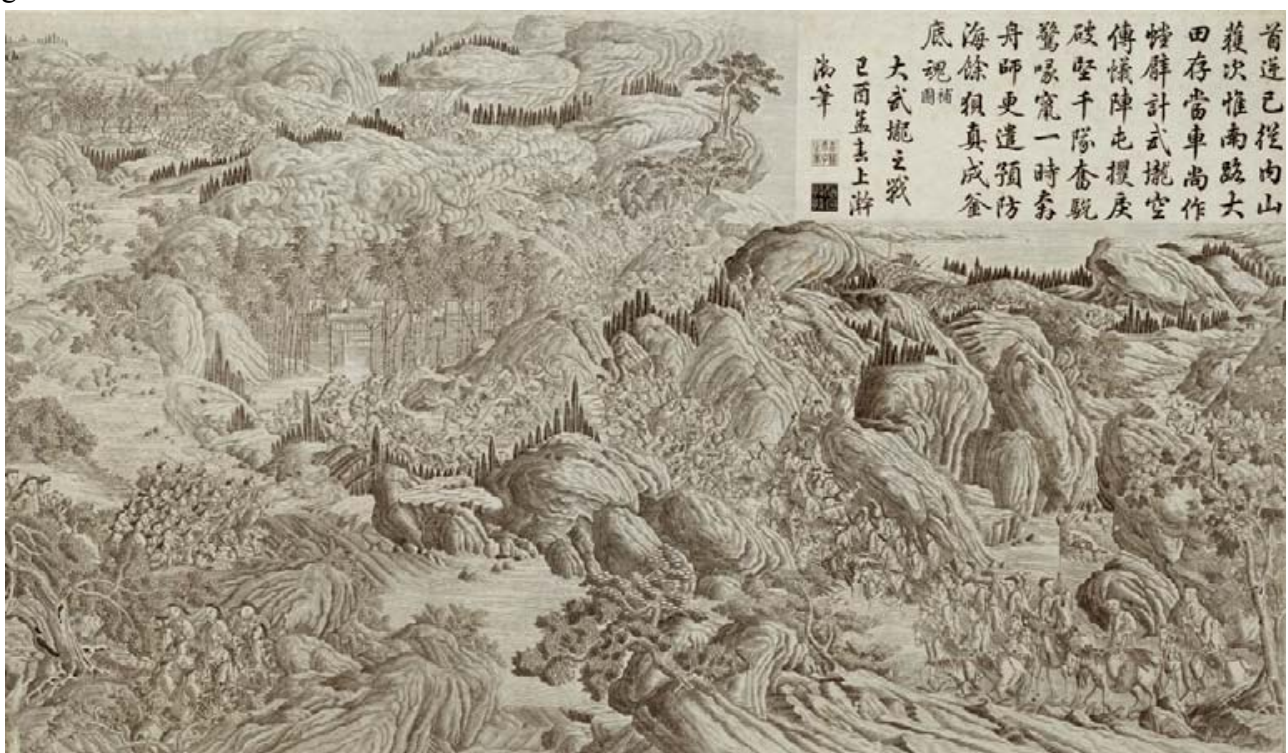

Figure 5. Campaign against Taiwan-Battle at Taivoan.

Emperor Qianlong, Qing Dynasty/ink printing on coated paper.

$58 \times 92.5 \mathrm{~cm}$.

With the development of the war, after the Qing army gradually cleared the northern Lin Shuang-Wen remnants, they turned to the south to attack Zhuang Da-Tian's associates. In January of the 53rd year of Qianlong (1788), several Qing armies went southward in order to occupy Taivoan southeast of Chiayi (now Yujing Township, Tainan County). This picture shows the Qing army's multi-faceted attack with strong gun powers, guns like rain farced Zhuang Da-Tian's associates to retreat, and Taivoan was taken by the Qing army.

Source of image: National Taiwan Museum of Fine Arts. 


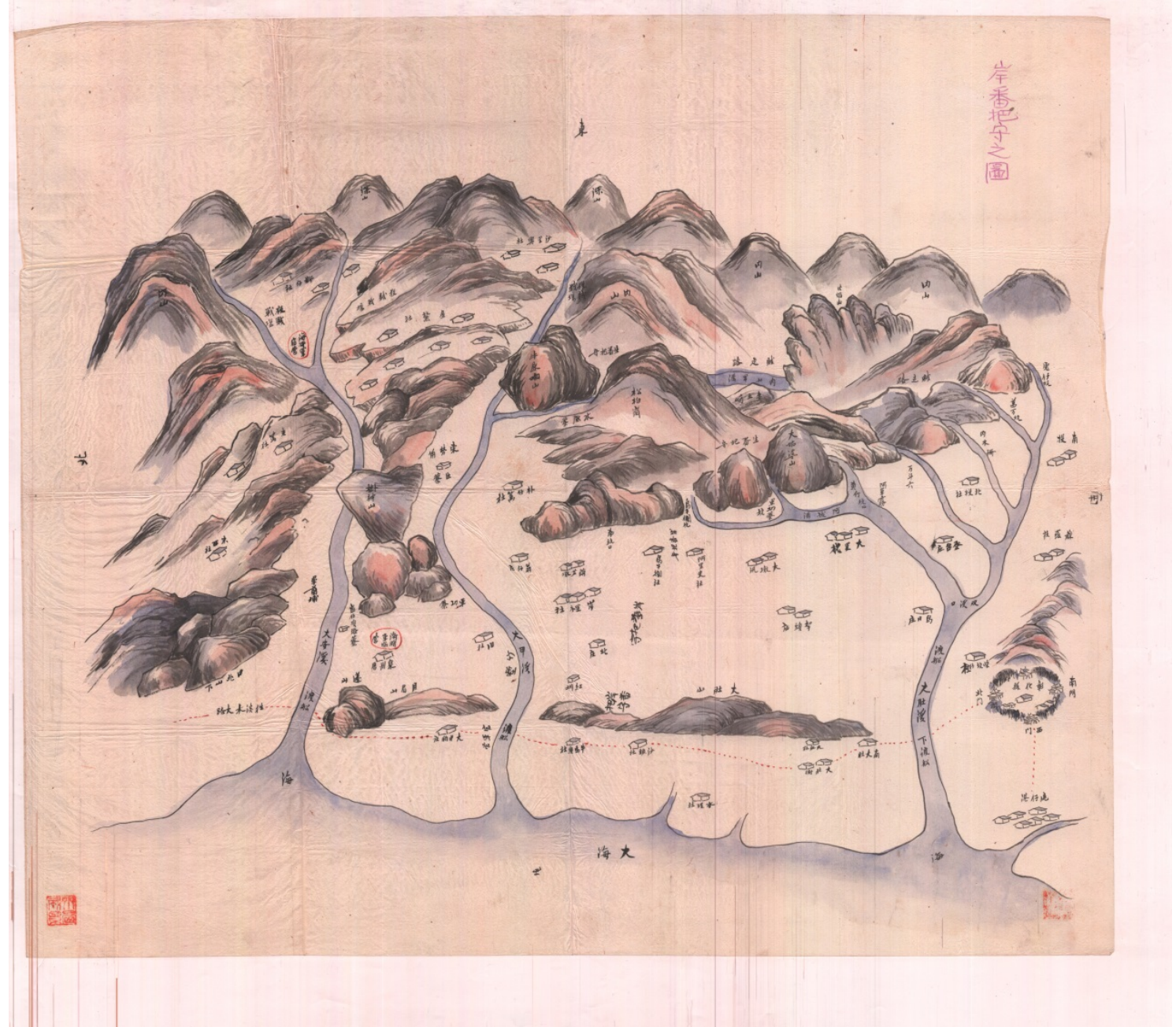

Figure 6. Shore Guard by Barbarians drawn by Inō Kanori.

Source of image:National Taiwan University Library.

In addition, look the Battle at Fangliao of sea and land attack (Figure 7). In the picture, along the coastline from top to bottom, a diagonal was oblique cut out; right on the sea was the Qing court navy, and every ship's cannon collided against the shore for shelling to prevent the rebels from fleeing from the sea. Coastal rebels could not escaped because behind them was the Qing cavalry in the plain with neat layout, ready to pursue. However, according to written reports, Fangliao campaign did not mention the navy sieged rebels at sea, but only said Fukanggan et al. pursued Zhuang Da-Tian, on the way encountering two thousand enemy. After the fight, the enemy was forced to the coast. Countless rebels jumped into the sea and flooded because no boat can be boarded. So this scene may be slightly confused with the Chaicheng battle of sea and land attack. On the battle of the Chaicheng, Fukanggan described at that time righteous people everywhere down from the ridge, straight to the coast; at that time it was just downwind, the navy densely spread over the ship at Chaicheng coast, so that the rebels jumped to the sea and shot and killed by the naval soldiers. It can be seen in the pursuit of Zhuang Da-Tian, more than once such battle occurred that chased the enemy to the coastal area to fight. And what the battle paintings focused was the scene that used the navy to conduct the sea and land attack. Navy was also deployed in capture of Zhuang Da-Tian, but no fire on the shore, which mainly played a coordination 
effect. In the relevant depiction of crossing the sea and navy, Campaign Against Taiwan clearly opened a new page for the battle painting drawing system. ${ }^{14}$

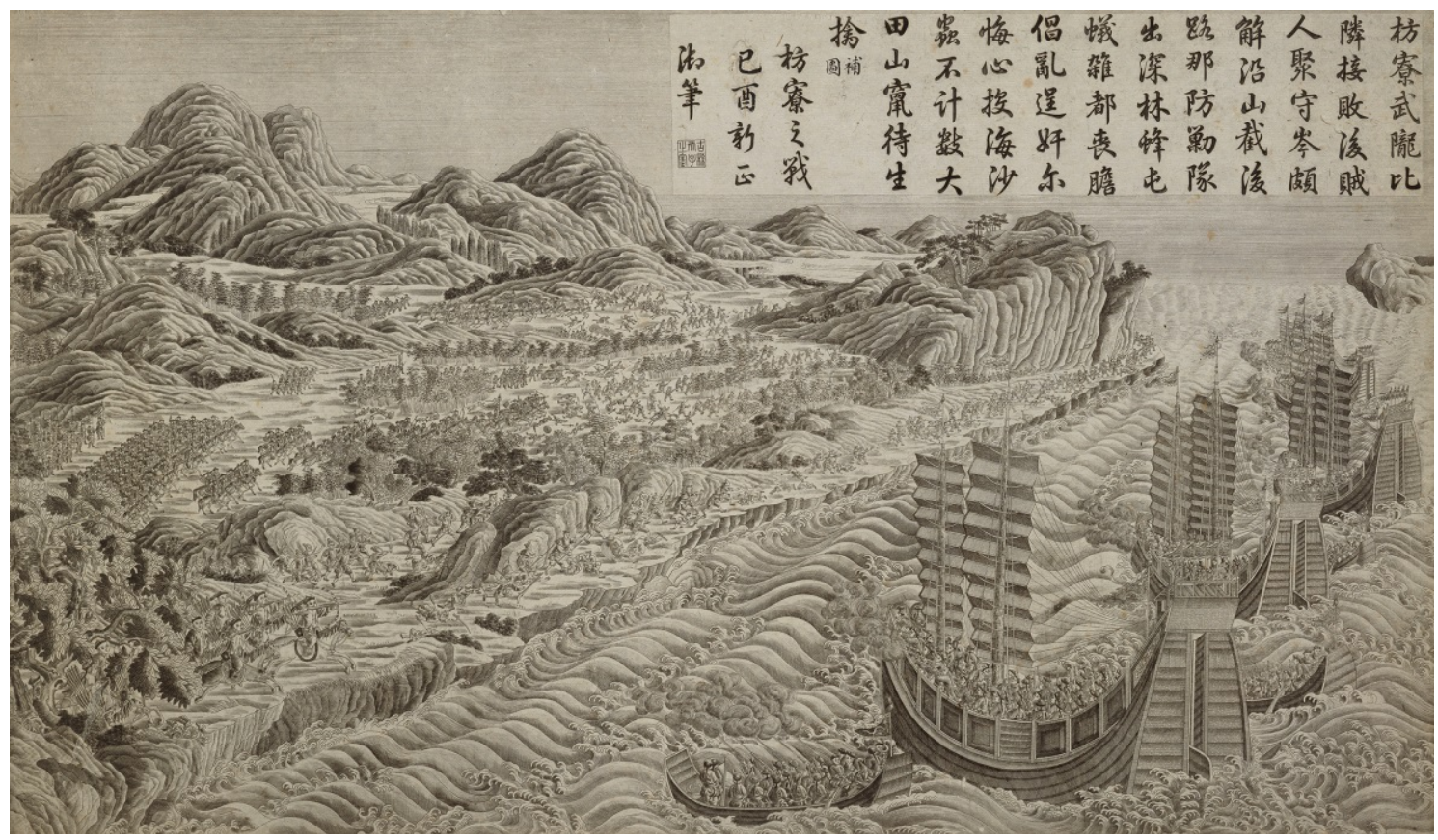

Figure 7. Campaign against Taiwan-Battle at Fangliao.

Emperor Qianlong, Qing Dynasty/ink printing on coated paper.

$58 \times 92.5 \mathrm{~cm}$.

In order to completely annihilate the rebels, the Qing army continued to go south, straightening other Zhuang Da-Tian's associates in Fangliao (now Pingtung County Fangliao Township, Pingtung County). It is clear in the picture that the Qing court rectified the queue, and under general Hailanqa's command, attacked by sea and land, and get southern indigenous people's response. In February of the 53rd year of Qianlong, the Qing army captured Zhuang Da-Tian.

Source of image: National Taiwan Museum of Fine Arts.

The emperor thought that all navy from the provinces were more than enough to fight against Taiwan, but all the troops were defeated, so the generals in Taiwan asked the emperor to send his general-Agui, and the soldiers of Manchuria. At that time the emperor's reply hoped that the Chinese people to solve their own things, did not need Manchu assistance, he rejected the request, and dispatched very young Fukanggan. At this time experienced officials were required, but also need the officials of Fujian to guide, so the emperor sent Lee Shiyao, whose talent and the genius of commanding the military was unparalleled, whether training army or recruiting, gained the great common aspiration of the people. He believed that this war is very easy, and convinced that these people they confronted just because the climate was too hot and nervous, or some disobedient robbers, as long as giving the terror with suppression, can let these people disappear. But arriving on the first day, they understood they were wrong, across the sea between Fujian and Taiwan, filled with Taiwan's warships, they could not go ashore. Manchu army was not used to this way of war, and immediately soldiers were discouraged. Fukanggan thought he can represent the emperor, and the victory of this campaign will bring him a higher honor, so that he will not pollute the name of Manchuria. He soon pleaded with the emperor, sending Agui to command the army; his presence can encourage all the soldiers. He proposed to the emperor all the military officers coming to meet him, so that all the forces will be concentrated, and thus defeat. ${ }^{15}$

\footnotetext{
${ }^{14}$ Hsin-Wei Li (2012). Op. cit., pp. 66-68.

15 l'Institut de France, MS1517, the letter written by Jean-Joseph Marie Amiot to Bertin, July 1, 1788, front p. 35.
} 
Compared with the Chinese literatures, Jean-Joseph Marie Amiot's letter added the difficulties encountered by the Manchu warships across the sea, especially warships and divers could let the Manchu warships quickly wreck; this war technique was unprecedented.

The letter highlighted this campaign different from the former pacification of East Turkestan, and Mongolia was due to a sea battle. The troops of the Qing Dynasty army were unable to fit, and it was difficult to arrive in Taiwan. The warships and battles of the sea were painted in a perspective way, and accurately portrayed.

In this the emperor's letter, it is clear that not the victory is death. This was the fate of Fukanggan. The difficulty for him was not to fight, but to the place of war. The army must go through the sea, through all the opposing forces of the warships, and could not distinguish between the enemy and our army, especially the Dutch ships. So over the whole journey, in order to avoid the disaster of wreck, especially through the shells at sea, while there were many diving people could stay in the sea for several hours and could not be defeated. These dives have a high talent; they sneaked into a ship and then holed by a few tools only, and in a very short time let the water flooded which was the way that these rebels used to have many ships wreck. Thus, it must go along the sea breeze, so that the journey all the way smooth and no wreck will be happened. ${ }^{16}$

With Lee Shiyao, the army arrived in Taiwan. ${ }^{17}$

Hsin-Wei Li (2012), The Creation of Copper-Engraved Battle Prints in the Era of Emperor Qianlong: From East Turkestan Campaign to Taiwan Campaign pointed out: The Crossing the Ocean and Triumphant Return depicted how Fukanggan and others peacefully returned to Xiaman after the war was settled. Among the Three Ministries' Border Defense Illustration woodcut in Ming Dynasty, there are three paintings as Pacification of Bandits, (Figure 9) depicting a large ocean and warships; however, three looks similar: All is at right side, a general standing on the small pieces of prominent rock with raising hands for command, and at left side, is a large transverse ocean, over which ships of simple lines are horizontally spread along the waves, and among which only one to two can be seen the cabin and other structures, and the rest are only shown by simple sails. The boats are juxtaposed with each other; there is no fighting situation. It is worth noting that all the hulls are all tilted from the lower left to the right upper, to create a sense of ups and downs of ships by fluctuating waves. However, even if the proportion of the largest screen is the vessel, the screen performance is still the focus the full size on the condescending and commanding general, rather than the sea fleet. In this regard, the composition of Crossing the Ocean and Triumphant Return is more special, which the direction of the ship is vertical to the direction of the waves, giving people the feeling of hardships. Far and near vessels are also from small to large, like a breakthrough picture to the viewers. Relatively speaking, Etching can portray more meticulous lines; however, Crossing the Ocean and Triumphant Return (Figure 10) did not show the attempt stressing the fine structure of vessels since the Song Dynasty, instead, as the Pacification of Bandits (Figure 9) of Three Ministries' Border Defense Illustration, focused on how does the ship advance on the waves. However, Crossing the Ocean and Triumphant Return did not emphasize the performance of the command officer; in fact, a large wave of ups and downs and sprays, as well as soldiers full of the ships is to accurately give the sense of military capacity and crossing the oceans. ${ }^{18}$

\footnotetext{
${ }^{16}$ 1'Institut de France, MS1517, the letter written by Jean-Joseph Marie Amiot to Bertin, No. July 1, 1788, p. 36.

17 l'Institut de France, MS1517, the letter written by Jean-Joseph Marie Amiot to Bertin, No. July 1, 1788, back of p. 36.

${ }^{18}$ Hsin-Wei Li (2012). Op. cit., pp. 60-62.
} 


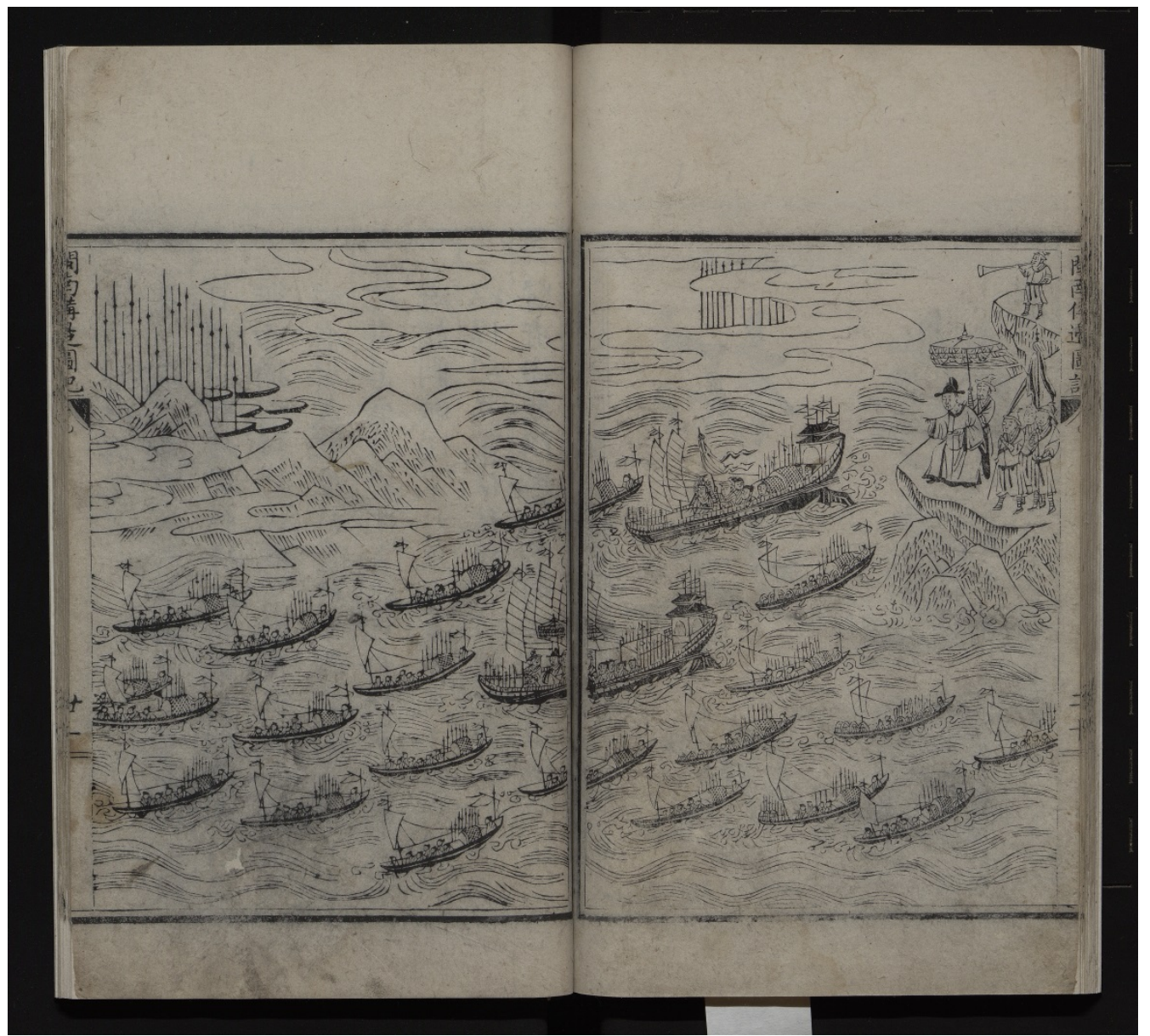

Figure 8. Woodcut in Ming Dynasty-Three ministries' border defense illustration—Pacification of Bandits in Tuolin. Source of image: http://news.china.com/history/all/11025807/20170122/30200834_all.html. (中國國家圖書館藏品)

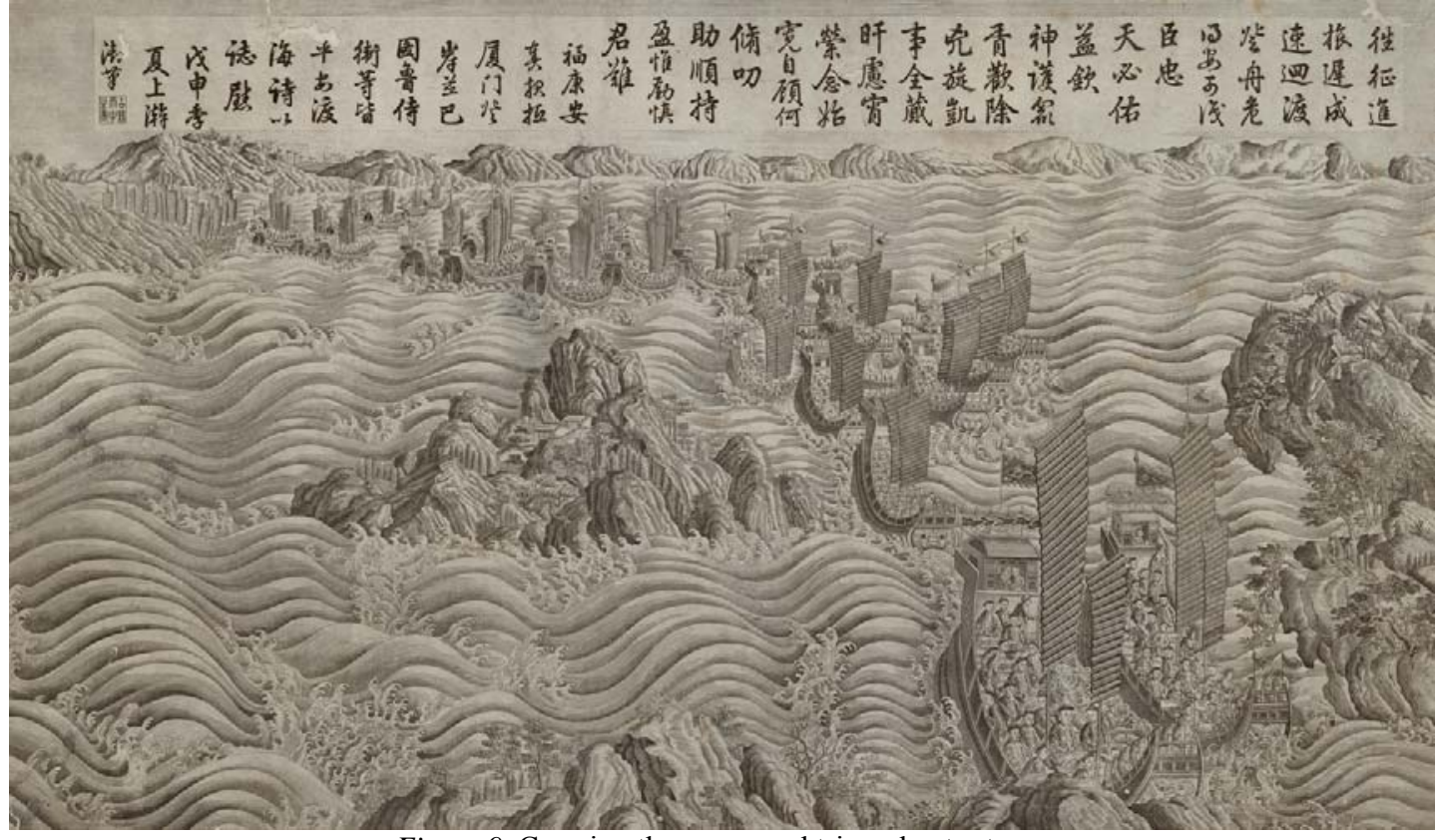

Figure 9. Crossing the ocean and triumphant return.

Source of image: National Taiwan Museum of Fine Arts. 
(4) Relying on the help of indigenous peoples, the French literatures proposed that Fukanggan treated Taiwan indigenous peoples with conciliation way that was the reason for this victory. We can see the indigenous peoples in two to three paintings, but the dress and appearance of the indigenous peoples is only a brief outline of the lines, and is very different from the real depiction of the dress of Qing's soldiers, which may lack knowledge and material, but the literatures also stressed the indigenous peoples.

He promised that their emperors would protect them and guaranteed the emperor's goodwill—survived in their way, and preserved the rights they had enjoyed in the past. Secondly: avoid being bullied by Han people when indigenous peoples and Han people do business. In these interests, indigenous peoples immediately obeyed and cooperated with the Qing soldiers to hand over all the rebels, women and children hiding in their homes, and let the soldiers enjoy all kinds of resources. All the rebel leaders all hid in the forest, the indigenous peoples received defeated troops and let them get lost, and secretly informed Fukanggan to successfully arrested them, and brought them to the front of the generals. We let Fukanggan understand that those people were unfortunate and brought all of them to the front of the generals. We could not expect such success, because we were afraid that some of indigenous peoples will oppose and secretly support the insurgents. However, it made the emperor and Manchuria very happy - they were able to fight in such a climate. The emperor's order hoped to take advantage of this opportunity to try to bring the indigenous peoples in China here, and distributed them in other different provinces to dominate Chinese. This was not most people's opinion, but the Emperor's advice. If Fukanggan failed, he had to make a war, so that Beijing's Manchuria began to act. The message of victor against Taiwan Island has been spread for two years. ${ }^{19}$

Therefore, in the Campaign Against Taiwan, there are many images of indigenous peoples' assistance. And also many supervisors reported Taiwan indigenous peoples participated in the batters that was cited before. In this regard, to search the paintings, we can find the scene depicting indigenous peoples in the inner mountain to attack the uprisers who fled into the mountains, and the most specific is the two paintings as Capture of Lin Shuang-Wen in Laoquqi (Figure 10) and Battle at Taivoan (Figure 5). In the left upper of the painting Capture of Lin Shuang-Wen in Laoquqi (Figures 10-1 and 10-2), and in the right upper (Figure 10-3), as well as the mountain area in the left upper of the painting Battle at Taivoan (Figure 5-1), all painted with settlements and fences, and it can be seen that out of the settlements, the indigenous people wearing long feather headdress, upper body naked, and only wearing animal skin-like skirt, holding swords, spears, or bowing like to externally attack. These scenes and figures should be in the presence of the picture that the indigenous peoples of Taiwan inner indigenous tribes collaborated with the Qing army to intercept Lin Shuang-Wen, Zhuang Da-Tian and other uprisers fleeing into the mountains. And in the direction corresponding to this picture, can also be found seemingly gangsters modeling people in groups into the mountains. ${ }^{20}$

\footnotetext{
19 1'Institut de France, MS1517, the letter written by Jean-Joseph Marie Amiot to Bertin, No. July 1, 1788, front and back of p. 37.

${ }^{20}$ Ho Meng-Hou, Taiwan Indigenous People in Lin Shuang-Wen Event in Qing Dynasty, National Palace Museum Academic Quarterly, Vol. 26, No. 4 (Taipei: National Palace Museum, 1999 summer), p. 128.
} 


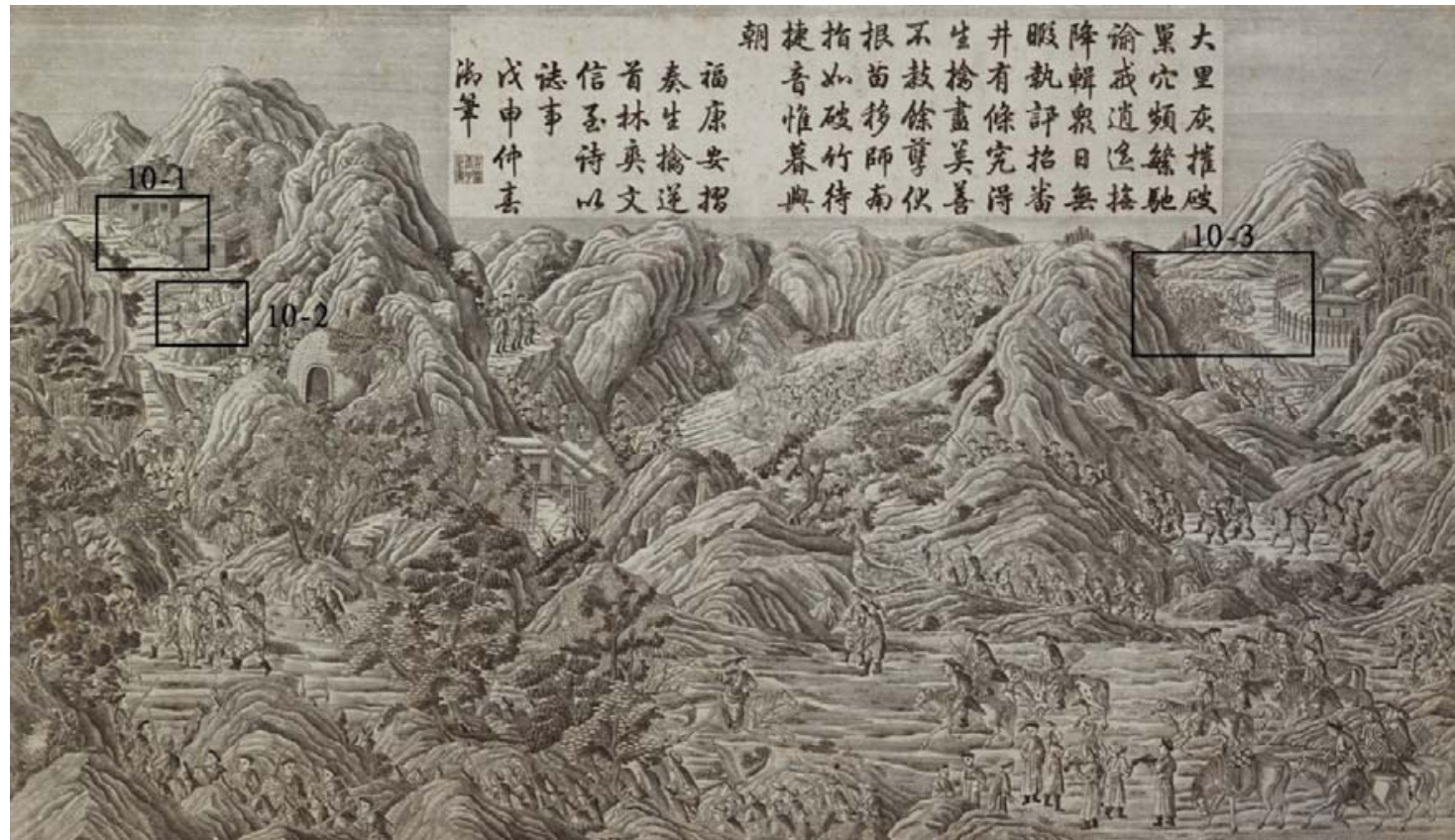

Figure 10. Campaign against Taiwan-Capture of Lin Shuang-Wen in Laoquqi.

Source of image: National Taiwan Museum of Fine Arts.

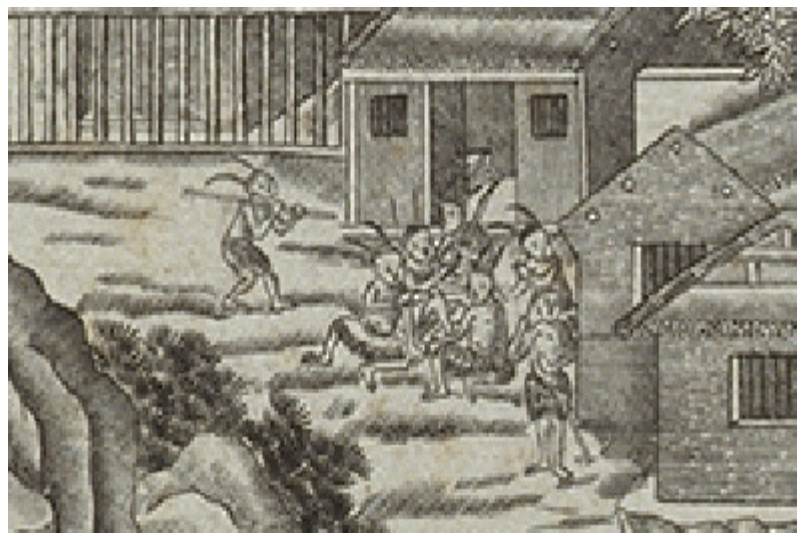

Figure 10-1. The indigenous peoples of mountains depicted in the upper left corner of the Campaign against Taiwan, Capture of Lin Shuang-Wen in Laoquqi.

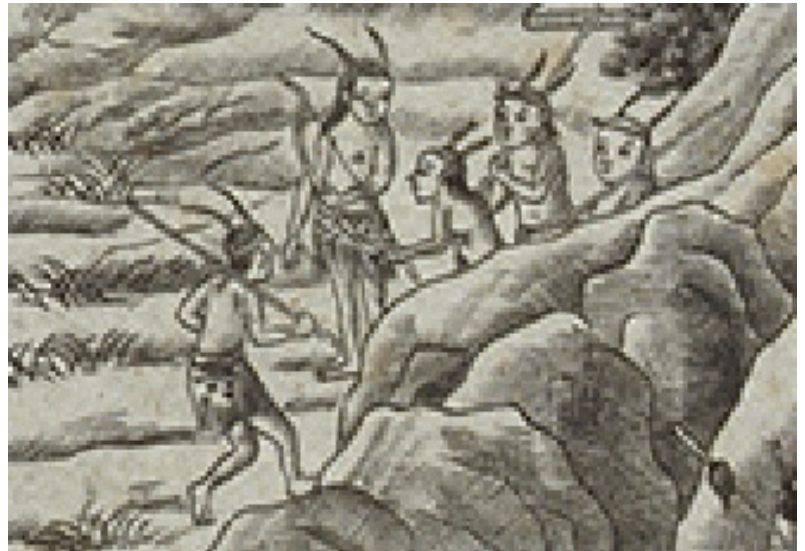

Figure 10-2. The indigenous peoples of mountains depicted in the upper left corner of the Campaign against Taiwan, Capture of Lin Shuang-Wen in Laoquqi. 


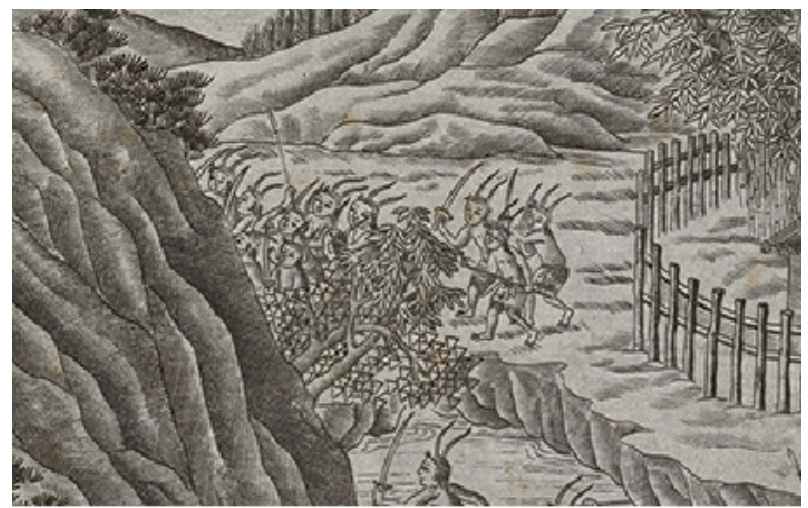

Figure 10-3. The indigenous peoples of mountains depicted in the upper right corner of the Campaign Against Taiwan, Capture of Lin Shuang-Wen in Laoquqi.

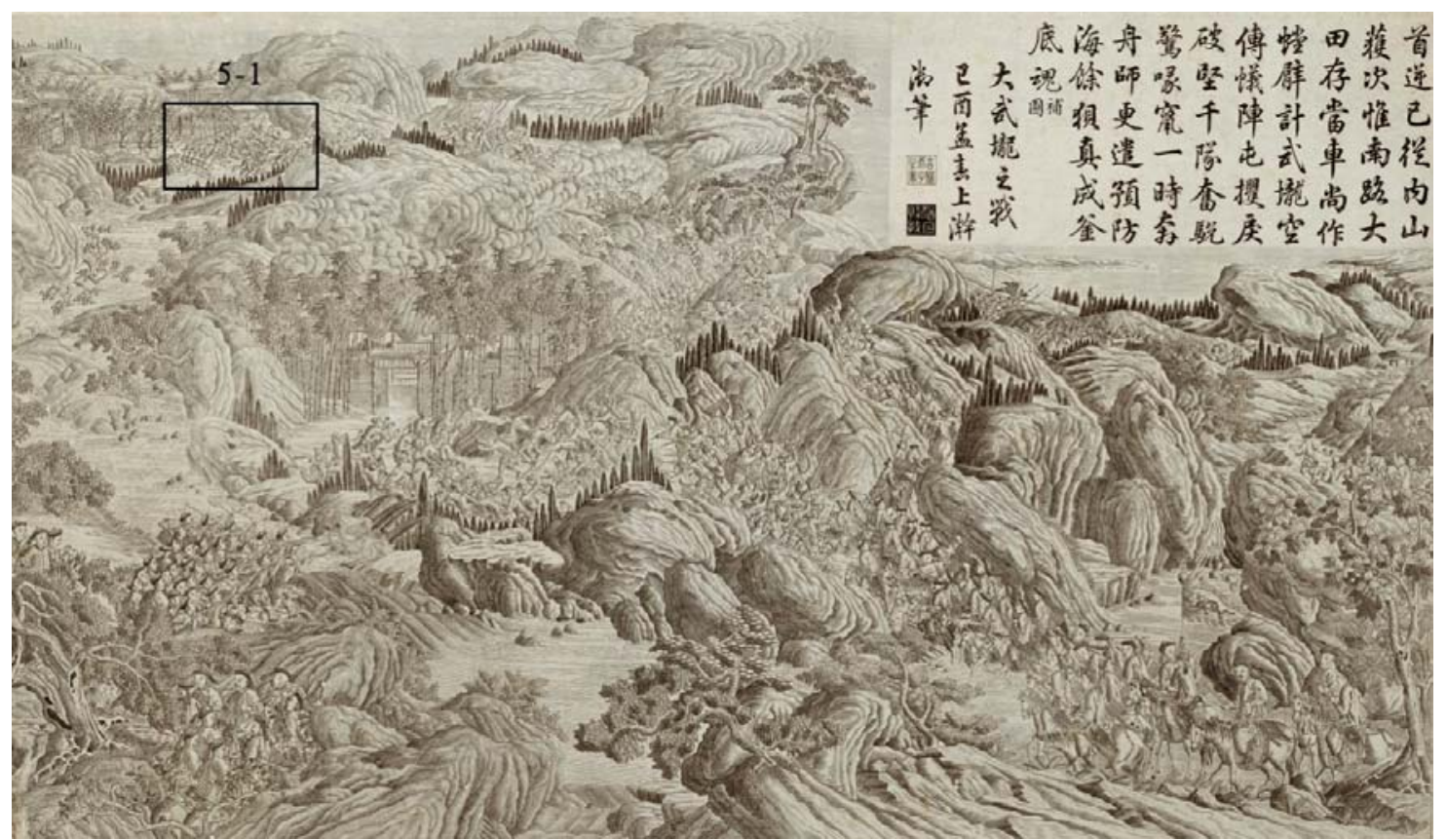

Figure 5. Campaign against Taiwan-Battle at Taivoan,

Source of image: National Taiwan Museum of Fine Arts.

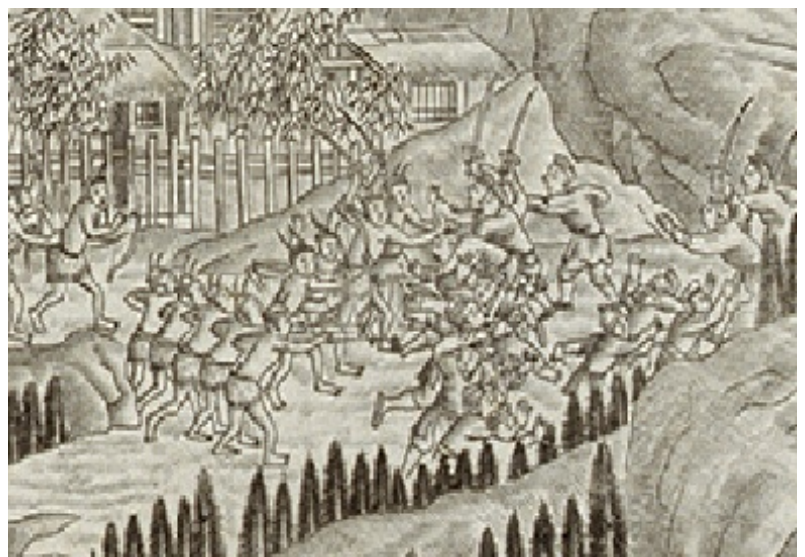

Figure 5-1. The indigenous peoples of mountains depicted in the upper left corner of the Campaign Against Taiwan-Battle at Taivoan. 
On the occasion of the war, the interpretation officer of the Anli tribe and Xu Monglin, the indigenous peoples management sub-prefecture of north region, and others who were familiar with the in exchange for assistance to the officials. At that time so called Wuao and other raw barbarians at that time are today's Atayal peoples. This paper has mentioned that on the occasion in the arrest of Lin Shuang-Wen occasion, Fukanggan made a general survey of subjective and objective situation, taking conciliation with indigenous tribes, and did not invade the indigenous areas with the army, perhaps due to his understanding of the domain concept of the indigenous people in mountain area and their always tough ethnicity.

As for the painted situation at the left upper corner of Battle at Taivoan is similar with the painting of Capture of Lin Shuang-Wen in Laoquqi, and there are indigenous tribes in the mountains, in which the characters are consistent; however, in terms of the history described by the paintings, when the Qing army attacked the south region straight to Taivoan where the headquarter of Zhuang Da-Tian, the uprising leader in south region, on the geography and the situation, Zhuang Da-Tian and others must take Taivoan as the best hiding place. The forgoing citied, on December 2, of the 52nd year of Qianlong, Fukanggan reported that in order to intercept the road for Zhuang Da-Tian into the mountain, he caused Liu Congjong, a xiucai who were familiar with the indigenous matters of middle region to go to Neiyo indigenous tribe behind Taivoan mountain, giving an explicit instructions to raw barbarians for assistance, and the place is about the mountain valley between two watershed of Nanzixian River and Laonong River in the east of Taiwan capital (now Tainan), where then officially identified as biosphere outside, in which the unnaturalized indigenous peoples in Taivoan mountain area should be Siraya of Pingpu indigenous peoples; in addition, the Neiyo indigenous tribe behind the Taivoan mountain should be later called the south Tsou people community.

(5) The emperor's reward and punishment after Lin Shuang-Wen Event; meritorious reward.

After pacification of Taiwan, Emperor Qianlong was very happy, so that the reward given to the meritorious officers must be quite generous. The chief commanders Fukanggan and Hailanqa were conferred duke, and rewarded gem cap, Magua surrounded by dragon pattern, four-hem robe, purple reins, and a plate of coral beads, etc.; Fukanggan was rewarded golden belt. Even a little relevant He Shen, the Emperor Qianlong's favored minister was also promoted and rewarded, whose merits in the pacification of Lin Shuang-Wen Event was “...always flattered the emperor's written instructions, and very clear about all Qing and Han people's events; hardworking and industrious, so should be given special reward" (Figure 11). ${ }^{21}$

The description of French literatures:

Fukanggan and Lee Shiyao were rewarded most. Fukanggan had the best eight houses which only the 1st level of nobility of the empire to have. One of the rewards was the most honorable nobility of the imperial, which can be passed to the next generation, and to all have princes with royal blood. The second part: he was rewarded with a title as the first level of the officials; the others were not so respectable. His status was higher than the Manchu people and Chinese. As for Lee Shiyao, I think what he got you do not feel Interest. I think, only added in the official rank. He rose to a level, and this upgrade was shown in the country. If there were reward and praise, and criminal responsibility and punishment were also imposed on the officials who did not do their duties - the court ignored the fact that these officials opposed the people - they were sentenced to death. As for other officials, if they did the right thing, regardless in Taiwan or Fujia, according to their severity of the error, their property may be confiscated and they may be exiled depending on their severity of offense. ${ }^{22}$

\footnotetext{
${ }^{21}$ Originally published in Emperor Qianlong's Veritable Records of Qing Dynasty, Vol. 1298, cited from Veritable Records of Qing Dynasty, Vol. 25, p. 442.

${ }_{22}$ 1'Institut de France, MS1517, the written by Jean-Joseph Marie Amiot to Bertin, No. July 1, 1788, back of p. 37, and p. 38.
} 


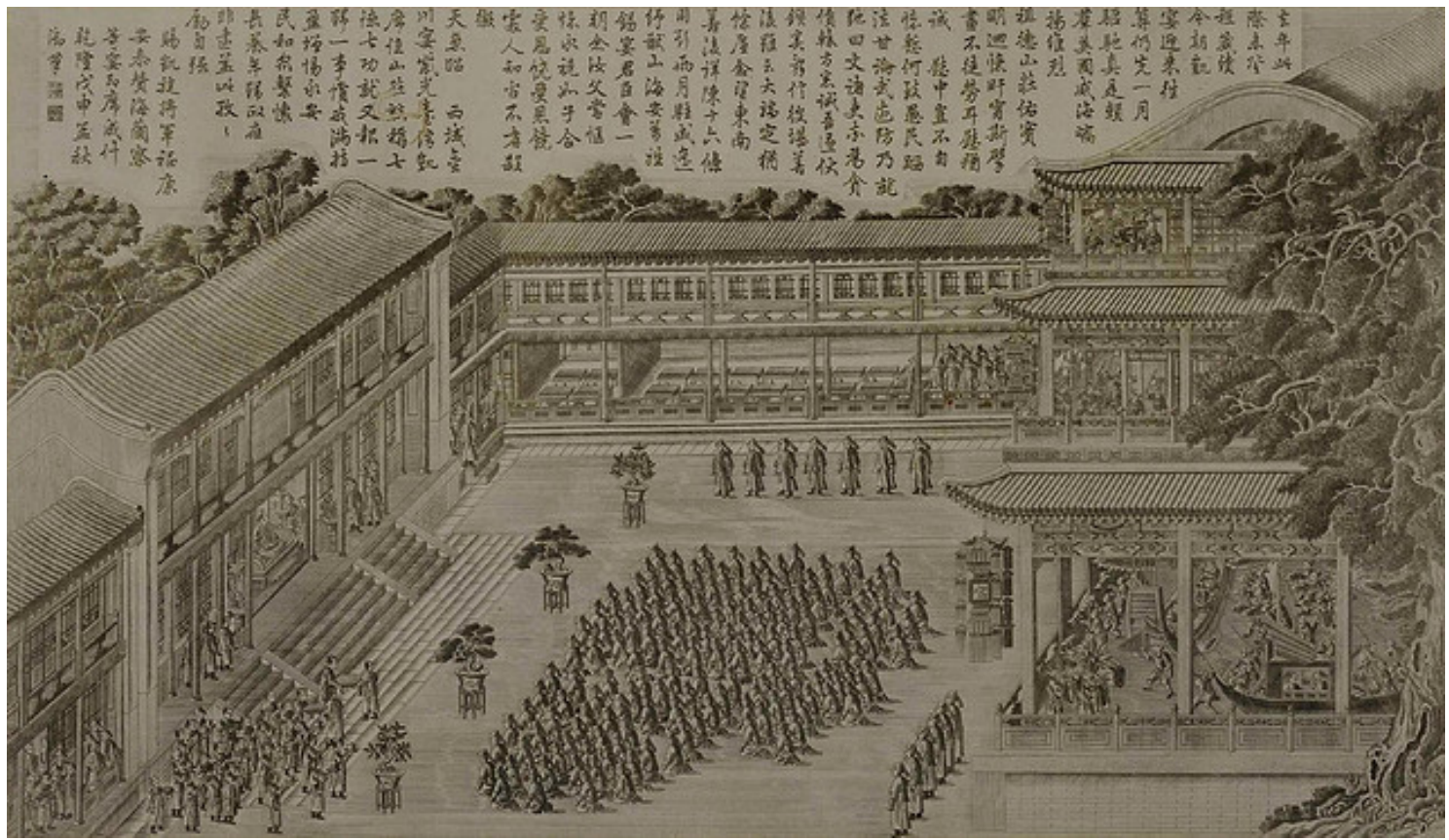

Figure 11.Campaign against Taiwan-Victory banquet.

Emperor Qianlong, Qing Dynasty/ink printing on coated paper.

$58 \times 92.5 \mathrm{~cm}$.

After the Qing court pacified western regions and Jinchuan, Qianlong had a feast at Ziguang Ge to reward soldiers. After the successfulpacification of Taiwan campaign, In the 53rd year of Qianlong (1788), Emperor Qianlong in Chengde, set the victory celebration feast in Qingyin Ge of Mountain Resort, to hospitalizeFukanggan, Hailanqa, and other soldiers who were meritorious in pacification of Taiwan.

Source of image: National Taiwan Museum of Fine Arts.

\section{Center and Border: The Ethnic Cultural Policy}

\section{Qianlong's Political Policy Towards Taiwan Indigenous peoples}

In Vol. 1319 of Emperor Qianlong's Veritable Records of Qing Dynasty, 1789, (the 53rd year of Qianlong), collected in National Palace Museum, clearly recorded four main figures who saw Emperor Qianlong in Beijing at that time: Duwashao, the indigenous boss of Taiwan Wubie head tribe, Abali, the indigenous boss of Alishan head tribe, Lebahong, the indigenous boss of Taivoan head tribe, and Jialiusai, the indigenous boss of Kuileishan head tribe, and others include indigenous bosses, interpretation officers and pass guards, a total of 42 people, among which Taiwan indigenous peoples accounted for the vast majority, and so called "raw barbarians" ${ }^{23}$ were the major in indigenous peoples, and the accompanied Han people's interpretation officers and pass guards were secondary; even among pass guards, there were also cooked barbarians, which are still different from raw barbarians. If in the arrangement of calling on the emperor or the feast given by the emperor, the raw barbarians boss were based. At that time the emperor's cognition was: "the righteous people and interpretation officers are the inland people whom raw barbarians cannot compare, and of more number, and do not have to seat in a feast, but are still rewarded as usual. ${ }^{24}$ From December 21 of the

\footnotetext{
${ }^{23}$ For example, the pass guard Lin Can who accompanied with Taivoan Tribe was the Jiaxianpu indigenous people, and Chang $\mathrm{Bu}$ was the people of Xiaoli Tribe of four Taivoan Tribes. Refer to Anping County Records, pp. 54-55.

${ }^{24}$ Square Imperial Edict Files, Winter file, the 53rd year of Qianlong, collected in National Palace Museum.
} 
53rd year of Qianlong (January 16, 1789) arriving in Beijing to January 17 of next year (February 11, 1789) leaving after Chinese New Year, they traveled in Beijing for nearly one month, during which in addition to calling on Emperor Qianlong, there were many important occasions being given the feast in the imperial city, such as Ying Tai, Fuchen Dian, Chonghua Gong, Baohe Dian, Ziguang Ge, and Shankaoshuichang Ge in the Old Summer Palace. ${ }^{25}$

\section{The Political Connotations and Pluralistic Groups of Territory Maps and Victory Paintings}

From the previous collations of this paper, we can see that after Taiwan was included in the territory, the Qing Dynasty emperor gradually contacted with the Taiwan indigenous peoples, and with the evolution of the process he had a different understanding, initially with "materialized" point of view, causing local officials to select Taiwan indigenous peoples who were good at running into Beijing for performance to please the emperor, and then with "dissident" vision considered that "raw barbarians were non-my servant, with different temperament and language barrier", and finally to the 53rd year of Qianlong (1789), all head tribe bosses of Taiwan's raw barbarians due to merits, went to Beijing to accept the Qing emperor's reward and hospitality, and with princes and ministers of Manchu, Mongolia, East Turkestan, and envoys of North Korea, Annan, and Siam to attend various feasts as the country guests. On this occasion, it seems to coincide with the imperial situation constructed by Emma Jinjua Teng. ${ }^{26}$ The same scene in Emperor Qianlong eighty-birthday party, in the 55th year of Qianlong (1790) was again on staged; Taiwan local officials, in the name of Emperor Qianlong's birthday party, reported and arranged the trip that 12 people, including Huaimuhuai, the boss of Lion Tribe, and other bosses of raw barbarians went to Beijing to see Emperor Qianlong. Emperor Qianlong also appointed Xu Sizeng, the Fujian governor at that time to take care of everything along the way; it can be described grand as usual. Especially, the trip going to Rehe for pilgrimage and feast were added. According to the record in the Emperor Qianlong's Veritable Records of Qing Dynasty, the 55th year of Qianlong: "On July 9 in early autumn, ...12 people, including Huaimuhuai, the boss of Taiwan raw barbarians for audience with the emperor... On the July 14, the Emperor granted ...Taiwan raw barbarians the feast at Dabochengjing Dian."

\section{Conclusion}

If it is widely seen, in the Lin Shuang-Wen Event occurred in the Qing Dynasty, which almost shake whole Taiwan, the indigenous peoples, including the identified raw barbarians and cooked barbarians can be said to be involved in the whole process. At the beginning of the incident, the cooked barbarians of plains aborigines of Anli and other settlements in the middle of Taiwan who should serve, and because they usually cooperated with the official and attached to the court for years; then a large number strong barbarians who should serve corvee were levied to guard the north shore of Dajia Riever, and played a role in blocking the spread of rebellion to the north. Till the midst of the event, when Lin Shuang-Wen and other rebels were fleeing into the mountains because of the obstruction in the war, the Qing court to contact the raw barbarians through Gaundong volunteers, the indigenous management sub-prefecture and cooked barbarians near mountain, succeeded in combining the forces of the unspecified indigenous peoples of the court, to prevent the perpetrators in the mountains from escapee, and finally Lin Shuang-Wen, Zhuang Da-Tian were captured, and then the chaos was quelled.

\footnotetext{
${ }^{25}$ History of Qing Royal Court, Vol. 7, inscription "A Feast Given in Yingtai”.

${ }^{26}$ Emma Jinhua Teng, Taiwan's Imagined Geography: Chinese Colonial Travel Writing and Pictures, 1683-1895. pp. 237-248.
} 
To control the people of Taiwan, the Qing court could not help using ethnic differences to achieve the purpose of its rule. From the beginning of the exploration period with the fuzzy and swinging ban policy, developed to the Qianlong period, it has been skilled use of the so-called "ethnic isolation policy", to divide the people of Taiwan from living space by tree ethnic groups as the Han people, cooked barbarians, and raw barbarians, and to intertwine the ethnic groups through policy manipulation to effectively control and use this contradictory relationship. Like the Yongcheng period has established raw barbarians as "external guard" to block Han people's cross-border reclamation. And then till the 33rd year of Qianlong, it formulated the Barbarian Place Protection Policy to actively strengthen the protection of cooked barbarians place, intending to settle the cooked barbarians outside the mountain near the flat ground, in order to form the intermediate zone to isolate raw barbarians and Han people, and then, under the guidance of the Protection System Setting \& Stationed Barbarians Troops Policy, actively formed an alliance with cooked barbarians, and effectively use the latter's force as a balanced power. The accumulation of these practices clearly played a considerable role in the process of suppressing the Lin Shuang-Wen Event, and sought the greatest benefit for the rulers.

In addition, comparing with Han dynasty who considered itself as the orthodox, the Qing Dynasty regime who entered the Central Plain with ethnic minority, its rulers indeed could adopt a more open attitude to accept the multi-cultures; in the premise of the consolidation of the regime, it most could give cultural identity and political recognition for the various ethnic groups in the national territory, such as the treatment of Mongolia, Tibet, and East Turkestan ethnic groups, especially the emperors from the early Qing Dynasty to Qianlong have shown such a mind. ${ }^{27}$

\section{References}

\section{First-hand information}

History of Qing Royal Court, Vol. 7, Description “A Feast Given in Yingtai”.

l'Institut de France, MS1517, the letter written by Jean-Joseph Marie to Bertin, October 1, 1788, pp. 34-40.

Ming and Qing Dynasties Historical Materials, Edition Wu, the 3rd book, p. 228, "A Report for Fujian Provincial Commander-in-chief of Navy, Huang Shi-Chien Extracted from the Cabinet", the document issued by Ministry of Punishments, September 22, the case of Yang Guang-Xun.

Originally published in Emperor Qianlong's Veritable Records of Qing Dynasty, Vol. 1298, cited from Veritable Records of Qing Dynasty, Vol. 25.

Originally published in Emperor Qianlong's Veritable Records of Qing Dynasty, Vol. 1300.Cited from Veritable Records of Qing Dynasty, Vol. 25. In addition, refers to Matters for Report of Comparing with the time of Zhu Yi-Gui and Lin Shuang-Wen Two Cases, reported by He Shen, the Grand Secretary of the Wenhua Palace on March 11 of the 53rd year of Qianlong. Refers to Compilation of Taiwan's Archives in Ming and Qing Dynasties, the third series, Vol. 35, pp. 206-207.

The Grand Council (Junjichu) Monthly Written Report, Box 2778, pack 161, No. 38231, November 10, the 53rd year of Qianlong, Chen Pi Report.

The Grand Council (Junjichu) Monthly Written Report, box 2778, pack 161, No. 38807, Lin Shuang-Wen Report. Veritable Records of Qing Dynasty. Beijing: Zhonghua Book Company, 1986-1987.

\section{Modern treatises}

Chuang, C.-F. (1987). A study on emperor Qianlong’s Ten Great Campaigns. Beijing: Zhonghua Book Company.

Ho, M.-H. (2007). Exhibitions special issue: “A hundred Years of View-Taiwan, Indigenous Peoples and Taitung in Historic Materials”. Taitung City: National Museum of Prehistory.

\footnotetext{
${ }^{27}$ Ho Meng-Hou, Taiwan Indigenous People in Lin Shuang-Wen Event in Qing Dynasty, No. 4, Vol. 2 of National Palace Museum Academic Quarterly (Taipei: National Palace Museum, 1999 summer), pp. 134-136.
} 
Ho, M.-H. 2009. Taiwan indigenous people in Lin Shuang-Wen Event in Qing Dynasty. National Palace Museum Academic Quarterly, 26(4), 119.

Hsu, W.-H. (2001). Lin Shuang-Wen Event and Taiwan historical development. National Palace Museum Academic Quarterly, 19(1), 95-150.

Huang, H.-Y. (1986). The contribution of Taiwan indigenous peoples to local public security in the Qing Dynasty: Righteous indigenous peoples and their function. Taipei Literatures, 75, 131-197.

Li, H.-W. (2012). The creation of copper-engraved battle prints in the era of emperor Qianlong: From East Turkestan Campaign to Taiwan Campaign (Unpublished master thesis). Graduate Institute of Art History, National Taiwan University, Taipei.

Lu, H.-Y. (2007). Lou Tong Zhu Sheng-The Qing Dynasty victory campaign print collected by National Palace Museum. The National Palace Museum Monthly of Chinese Art, 293, 40-51.

National Palace Museum, (2007). New Vision-Giuseppe Castiglione and Western-style Qing Palace (hardcover). Taipei: National Palace Museum.

Teng, E. J. (2004). Taiwan's imagined geography: Chinese colonial travel writing and pictures, 1683-1895. Harvard East Asian Monographs, number 230. Cambridge: Harvard University Asia Center. 